\title{
Aflatoxins and kwashiorkor: a study in Sudanese children
}

\author{
R G HENDRICKSE，J B S COULTER，S M LAMPLUGH，S B J MACFARLANE，T E WILLIAMS, \\ M I A OMER, G I SULIMAN
}

\begin{abstract}
Blood and urine samples from 252 Sudanese children were investigated for their aflatoxin content by highperformance liquid chromatography. The children comprised 44 with kwashiorkor, 32 with marasmic kwashiorkor, 70 with marasmus, and 106 age-matched, normally nourished controls. Aflatoxins were detected more often and at higher concentrations in sera from children with kwashiorkor than in the other malnourished and control groups. Aflatoxicol, a metabolite of aflatoxins $B_{1}$ and $B_{2}$, was detected in the sera of children with kwashiorkor and marasmic kwashiorkor but not in the controls and only once in a marasmic child. The difference between children with kwashiorkor or marasmic kwashiorkor and those in the control or marasmus groups was significant. Urinary aflatoxin was most often detected in children with kwashiorkor but their mean concentration was lower than in the other groups. Aflatoxicol was not detected in urine in any group.

These findings suggest either that the children with kwashiorkor have a greater exposure to aflatoxins or that their ability to transport and excrete aflatoxins is impaired by the metabolic derangements associated with kwashiorkor. The presence of aflatoxicol in the sera of children with kwashiorkor but not in the others suggests
\end{abstract}

\footnotetext{
Department of Tropical Paediatrics, School of Tropical Medicine, Liverpool L3 5QA

R G HENDRICKSE, MD, FRCP, professor

J B S COULTER, MB, MRCPI, senior lecturer

$S M$ LAMPLUGH, MSC, research assistant

S B J MACFARLANE, BA, MSC, lecturer in statistics

T E WILLIAMS, MIST, chief technician

Department of Paediatrics and Child Health, University of Khartoum, Khartoum, Sudan

M I A OMER, MB, FRCP, professor

Children's Emergency Hospital, Khartoum, Ministry of Health, Sudan

G I SULIMAN, MB, MRCP, director
}

a difference in metabolism between the two groups. Further studies are needed, and measurement of aflatoxins in the food eaten by these children is already underway.

\section{Introduction}

The spectrum of protein energy malnutrition includes both marasmus and kwashiorkor. The pathogenesis of marasmus presents no mysteries: it is the childhood equivalent of chronic starvation, has clinical features that show few variations from case to case, and has been recognised in all societies, worldwide, from time immemorial to the present. In contrast, kwashiorkor remains a disease of obscure pathogenesis ${ }^{12}$ with clinical features that range from slight oedema in an unhappy child to gross oedema in a morbidly depressed child with grotesque skin lesions, severely deranged biochemistry, and depressed immunological functions. Kwashiorkor was first recognised in tropical Africa in the $1930 \mathrm{~s}^{3}{ }^{4}$ and subsequent reports of the syndrome have come almost exclusively from tropical or subtropical countries.

The earlier concept that kwashiorkor was caused by severe protein deficiency in the presence of relative carbohydrate (energy) excess ${ }^{5}$ became untenable when Gopalan showed in 1968 that there were no essential differences in the protein:energy ratios in the diets between children who developed marasmus and those with kwashiorkor. ${ }^{6}$ Gopalan postulated that kwashiorkor resulted from a "dysadaptation" of biochemical mechanisms that protect essential organs such as the liver at the expense of less essential tissues such as muscle during protein energy malnutrition. The cause of this postulated dysadaptation remains obscure.

Animal studies have shown several metabolic effects of aflatoxins which are similar to derangements consistently found in kwashiorkor, including hypoalbuminaemia, ${ }^{7}$ fatty liver, ${ }^{8}$ and immunosuppression. ${ }^{9}$ Foods in tropical developing countries are often contaminated by mycotoxins either constantly or seasonally. ${ }^{10}$ Warmth and high humidity provide optimum conditions for growth of many molds. ${ }^{11}$ The distribution and seasonal fluctuations of mycotoxin contamination of food are remarkably similar to the geographical distribution and seasonal prevalence 
of kwashiorkor, which tends to peak in the wet season in many areas. Reasons advanced to explain the seasonal occurrence of kwashiorkor include fluctuations in price and availability of food and seasonal prevalence of infections such as measles and gastroenteritis, ${ }^{12-14}$ but none of these factors can be universally applied to explain the seasonality of kwashiorkor.

We report here the preliminary findings of an investigation which seeks to determine the relations between mycotoxins, in particular aflatoxins, in food and malnutrition in childhood, with particular reference to the pathogenesis of kwashiorkor.

\section{Patients and methods}

Plan of study-A collaborative research project between the Department of Tropical Paediatrics, Liverpool School of Tropical Medicine, and the Department of Paediatrics and Child Health, University of Khartoum, and the Ministries of Health and Agriculture, Sudan, began in February 1981 and is planned to run for three years. The study is both epidemiological and clinical. Commonly eaten foods from local markets in Khartoum are screened each month for mycotoxins, and samples of food prepared in the homes of study subjects and controls are similarly screened. The clinical studies are being undertaken by a paediatrician seconded from Liverpool (JBSC) in collaboration with Sudanese colleagues in the Soba University

TABLE I-Presence of aflatoxin in Khartoum market foods (single test samples) and types of aflatoxins found

\begin{tabular}{lcll}
\hline & \multicolumn{4}{c}{ Detection method } \\
\cline { 2 - 4 } \multicolumn{1}{c}{ Sample } & Minicolumn & $\begin{array}{c}\text { Thin-layer } \\
\text { chromatography }\end{array}$ & $\begin{array}{c}\text { High-performance } \\
\text { liquid chromatography } \\
\text { (pg/g) }\end{array}$ \\
\hline Groundnuts & - & $+, \mathrm{B}_{1}, \mathrm{~B}_{2}$ & $\mathrm{G}_{2} 23, \mathrm{~B}_{2} 370, \mathrm{~B}_{1} 59666$ \\
Groundnuts (limed) & + & $+, \mathrm{B}_{1}, \mathrm{G}_{1}, \mathrm{G}_{2}$ & $\mathrm{G}_{2} 6, \mathrm{G}_{1} 2816, \mathrm{~B}_{1} 3517$ \\
Chickpeas & + &,,$+ \mathrm{B}_{1}$ & $\mathrm{~B}_{1} 876$ \\
Lentils & - & - & - \\
Haricot beans & + &,$- \mathrm{G}_{2}$ & - \\
Dried tomatoes & + & - & - \\
Foul musri & - &,$- \mathrm{B}_{2}$ & - \\
Sorghum & + &,$+ \mathrm{G}_{2}$ & $\mathrm{G}_{2} 12675$ \\
Dried ochra & - & - & - \\
Rice & - & - & - \\
Chilli powder & + & $+, \mathrm{B}_{1}, \mathrm{~B}_{2}$ & $\overline{\mathrm{G}}_{1} 84500, \mathrm{~B}_{1} 26300$, \\
Peanut butter & + & & $\mathrm{B}_{2} 9720$ \\
\hline
\end{tabular}

Teaching Hospital and the Children's Emergency Hospital, Khartoum. Foods are screened for mycotoxins in the Sudan, but representative samples are also sent to Liverpool for analysis. Serum and urine samples from study subjects are sent frozen to Liverpool for mycotoxin analyses.

Clinical studies-Children presenting with kwashiorkor (Wellcome Classification ${ }^{15}$ ) served as index cases and were studied in parallel with children with marasmus and marasmic kwashiorkor (body weight of less than $60 \%$ of the Boston 50th weight centile) of similar age and sex. The controls were well-nourished children (body weight of over $80 \%$ of the Boston 50th centile) in the same age range as the malnourished subjects admitted for minor intercurrent illness or for surgery. All children had a full history taken and underwent clinical examination, anthropometric measurements, and diet analysis.

Laboratory studies-All malnourished children had appropriate routine haematological, biochemical, bacteriological, and radiological investigation, and their blood and urine were analysed for aflatoxins. The controls underwent routine screening of urine for aflatoxin content; blood was not routinely drawn, but when an opportunity arose to obtain blood from a control it was examined for aflatoxins. Aflatoxin concentrations in serum and urine were determined by high-performance liquid chromatography using fluorescence detection and two-dimensional thin-layer chromatography. These were performed on serum after hexane partition and chloroform extraction ${ }^{16}$ and on urine after chloroform extraction and a silica-column clean up (H P Van Egmond, personal communication). Foods obtained from homes and the market were screened by minicolumn fluorescence, thin-layer chromatography, and high-performance liquid chromatography. Peanut butter was extracted using the official method of analysis recommended by the Association of Official Analytical Chemists, ${ }^{17}$ and all other foods were extracted using the rapid screening method of Holaday and Lansden. ${ }^{18}$

Statistical methods-Contingency tables showing numbers positive for aflatoxins were explored using log-linear modelling. The exact probability was calculated in a two-by-two table when cell numbers were small. The distributions of aflatoxin concentrations showed evidence of skewness. The data were therefore transformed to logarithms for comparison of means using analysis of variance.

\section{Results}

The results given here are those to date and are restricted to initial analyses for aflatoxins in food, serum, and urine.

Food analysis-Aflatoxins have been detected by high-performance liquid chromatography in the following foods obtained from local markets: groundnuts (plain and limed), chickpeas, dried ochra, and peanut butter (table I). Aflatoxins have not so far been detected in foul musri, rice, lentils, chilli, haricot beans, dried tomatoes, or sorghum. In addition to aflatoxins other (as yet unidentified) fluorescent substances have been detected in all foods tested except rice and lentils.

Aflatoxins in serum-A total of 177 sera have been screened. Aflatoxins were detected in the serum of children in all nutritional groups included in the study (table II). Aflatoxins were detected least often in the controls $(15.9 \%)$, marginally more often in children with marasmus $(19.3 \%)$ and marasmic kwashiorkor $(21.9 \%)$, and most often in those with kwashiorkor $(36.4 \%)$. In the three malnourished groups aflatoxins were more often detected in boys than in girls Analysis using log-linear modelling indicated that a model including nutrition as a factor would adequately describe the observed number positive for aflatoxins. There was evidence of a positive association between poor nutritional state and the presence of aflatoxins-in particular, the proportion positive in the kwashiorkor group differed significantly from that in the control group at the $5 \%$ level. Aflatoxicol was detected in the serum of six children with kwashiorkor and four children with marasmic kwashiorkor. It was not detected in any of the controls and there was only one identification in the marasmus group (table II). The difference between the proportions positive for aflatoxicol among children with kwashiorkor and marasmic kwashiorkor and the proportions positive among controls and children with marasmus was statistically significant (exact $p=0.0021$ ). Serum concentrations of the individual aflatoxins $B_{1}, B_{2}, G_{1}, G_{2}, M_{1}, M_{2}$, and aflatoxicol were measured. The results are presented in the figure and in table III, which gives means, SEMs for the logarithms of the observations, and geometric means in $\mathrm{pg} / \mathrm{ml}$. Values were highest in children with kwashiorkor and lowest in controls. Analysis of variance indicated that the differences between the means of the four nutritional groups was just significant $(\mathrm{F} 3 ; 37 \mathrm{df}=2.91 ; \mathrm{p} \simeq 0.05)$. In particular, the mean of the kwashiorkor group differed significantly from that of the controls $(t=2 \cdot 8,21 \mathrm{df}, \mathrm{p} \simeq 0 \cdot 01)$.

TABLE II-Detection of aflatoxin and aflatoxicol in 177 serum samples

\begin{tabular}{|c|c|c|c|c|c|c|c|c|}
\hline \multirow{3}{*}{$\begin{array}{l}\text { Nutritional } \\
\text { group }\end{array}$} & \multicolumn{6}{|c|}{ Aflatoxin } & \multicolumn{2}{|c|}{ Aflatoxicol } \\
\hline & \multicolumn{2}{|c|}{ Boys } & \multicolumn{2}{|c|}{ Girls } & \multicolumn{2}{|c|}{ Total } & \multirow{2}{*}{$\begin{array}{c}\text { No } \\
\text { tested }\end{array}$} & \multirow{2}{*}{$\begin{array}{l}\text { No }(\%) \\
\text { positive }\end{array}$} \\
\hline & $\begin{array}{c}\text { No } \\
\text { tested }\end{array}$ & $\begin{array}{l}\text { No }(\%) \\
\text { positive }\end{array}$ & $\begin{array}{c}\text { No } \\
\text { tested }\end{array}$ & $\begin{array}{l}\text { No }\left({ }^{\circ}\right) \\
\text { positive }\end{array}$ & $\begin{array}{c}\text { No } \\
\text { tested }\end{array}$ & $\begin{array}{l}\text { No }(\%) \\
\text { positive }\end{array}$ & & \\
\hline $\begin{array}{l}\text { Control } \\
\text { Marasmus } \\
\text { Marasmic kwashiorkor } \\
\text { Kwashiorkor }\end{array}$ & $\begin{array}{l}21 \\
31 \\
16 \\
23\end{array}$ & $\begin{array}{l}3(14 \cdot 3) \\
7(22 \cdot 6) \\
5(31 \cdot 3) \\
9(39 \cdot 1)\end{array}$ & $\begin{array}{l}23 \\
26 \\
16 \\
21\end{array}$ & $\begin{array}{l}4(17 \cdot 4) \\
4(15 \cdot 4) \\
2(12 \cdot 5) \\
7(33 \cdot 3)\end{array}$ & $\begin{array}{l}44 \\
57 \\
32 \\
44\end{array}$ & $\begin{array}{r}7(15 \cdot 9) \\
11(19 \cdot 3) \\
7(21 \cdot 9) \\
16(36 \cdot 4)\end{array}$ & $\begin{array}{l}44 \\
57 \\
32 \\
44\end{array}$ & $\begin{array}{l}0 \\
1(1 \cdot 8) \\
4(12 \cdot 5) \\
6(13 \cdot 6)\end{array}$ \\
\hline Total & 91 & $24(26 \cdot 4)$ & 86 & $17(19 \cdot 8)$ & 177 & $41(23 \cdot 2)$ & 177 & $11(6 \cdot 2)$ \\
\hline
\end{tabular}


Aflatoxins in urine-A total of 250 urine specimens were screened for aflatoxins. The overall detection rate in the four nutritional groups (table IV) studied was similar to that for aflatoxins in serum. The two groups with the highest proportions positive were girls with marasmus and kwashiorkor. Aflatoxicol was not detected in urine. Table III shows that children with kwashiorkor had lower concentrations of aflatoxin in their urine than the other groups and that the highest concentrations occurred among children with marasmus and marasmic kwashiorkor. Analysis of variance indicated no significant differences between the means of the four nutritional groups.

TABLE III-Concentrations of aflatoxins $(\mathrm{pg} / \mathrm{ml})$ detected in 41 samples of serum and in 61 urine samples

\begin{tabular}{|c|c|c|c|c|c|c|}
\hline \multirow{2}{*}{$\begin{array}{l}\text { Nutritional } \\
\text { group }\end{array}$} & \multicolumn{3}{|c|}{ Serum } & \multicolumn{3}{|c|}{ Urine } \\
\hline & No & $\begin{array}{c}\text { Mean } \\
\left(\begin{array}{c}\text { SEM }) \\
\text { loge }\end{array}\right.\end{array}$ & $\begin{array}{c}\text { Geometric } \\
\text { mean }\end{array}$ & No & $\begin{array}{c}\text { Mean } \\
\left(\begin{array}{c}\text { SEM }) \\
\text { loge }\end{array}\right.\end{array}$ & $\begin{array}{c}\text { Geometric } \\
\text { mean }\end{array}$ \\
\hline Control & 7 & $\begin{array}{c}4 \cdot 34 \\
(0 \cdot 44)\end{array}$ & 77 & 21 & $\begin{array}{l}5 \cdot 25 \\
(0.31)\end{array}$ & 191 \\
\hline Marasmus & 11 & $\begin{array}{l}5.35 \\
(0.48)\end{array}$ & 211 & 18 & $\begin{array}{l}6.23 \\
(0.49)\end{array}$ & 508 \\
\hline$\underset{\text { kwashiorkor }}{\text { Marasmic }}$ & 7 & $\begin{array}{c}6.02 \\
(0.67)\end{array}$ & 412 & 8 & $\begin{array}{l}6 \cdot 61 \\
(0.60)\end{array}$ & 742 \\
\hline Kwashiorkor & 16 & $\begin{array}{l}6.56 \\
(0.50)\end{array}$ & 706 & 14 & $\begin{array}{l}5.13 \\
(0.46)\end{array}$ & 143 \\
\hline
\end{tabular}

\section{Discussion}

The findings in this investigation so far provide firm evidence that children in the Sudan are exposed to aflatoxins in their diets and that these substances can be detected in the serum and urine of a high proportion of the population of young children.

Circumstantial evidence of the role of aflatoxins in human disease includes epidemiological correlations between aflatoxins in food and hepatoma in Africa and Thailand, ${ }^{19}$ severe liver

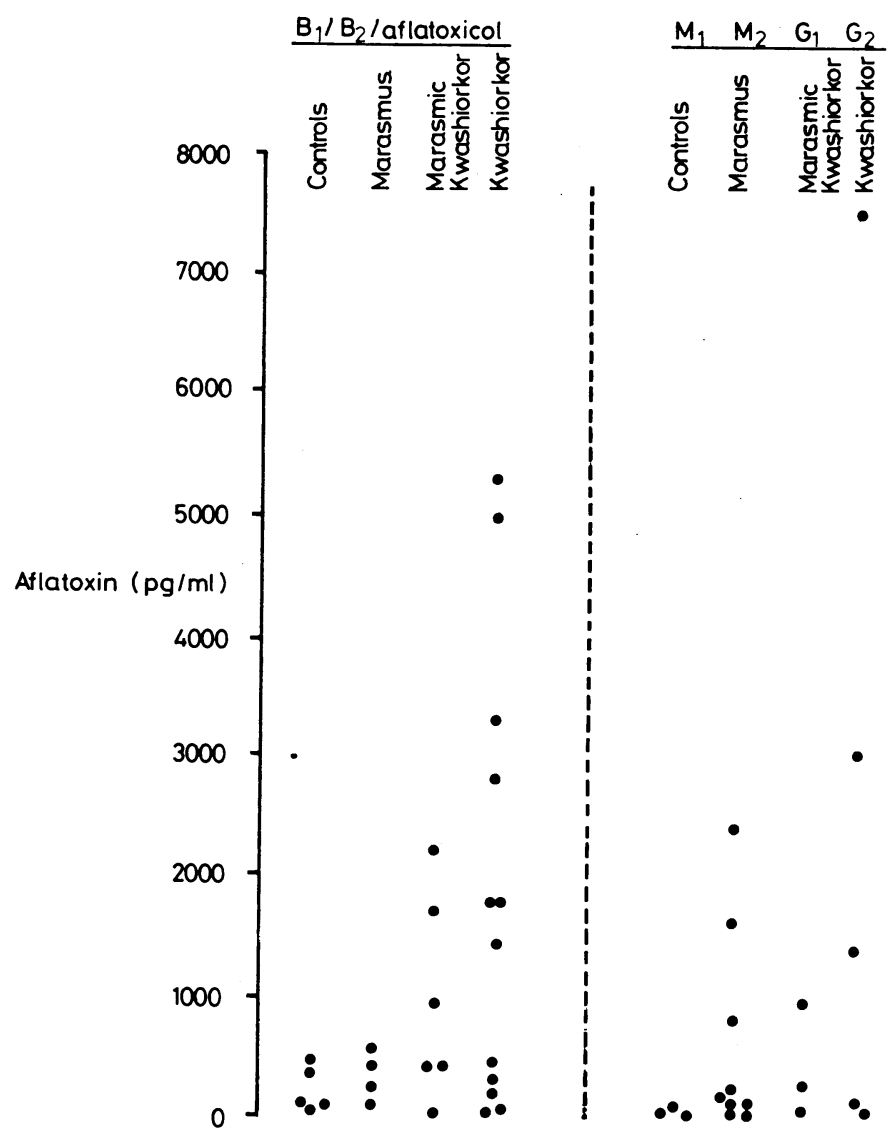

Concentrations of aflatoxins detected in 43 positive serum samples.

TABLE IV-Detection of aflatoxin in 250 urine samples

\begin{tabular}{|c|c|c|c|c|c|c|}
\hline \multirow{2}{*}{$\begin{array}{l}\text { Nutritional } \\
\text { group }\end{array}$} & \multicolumn{2}{|c|}{ Boys } & \multicolumn{2}{|c|}{ Girls } & \multicolumn{2}{|c|}{ Total } \\
\hline & $\begin{array}{c}\text { No } \\
\text { tested }\end{array}$ & $\begin{array}{l}\text { No }(\%) \\
\text { positive }\end{array}$ & $\begin{array}{c}\text { No } \\
\text { tested }\end{array}$ & $\begin{array}{l}\text { No }(\%) \\
\text { positive }\end{array}$ & $\begin{array}{c}\text { No } \\
\text { tested }\end{array}$ & $\begin{array}{l}\text { No }(\%) \\
\text { positive }\end{array}$ \\
\hline $\begin{array}{l}\text { Control } \\
\text { Marasmus } \\
\text { Marasmic kwashiorkor } \\
\text { Kwashiorkor }\end{array}$ & $\begin{array}{l}61 \\
41 \\
15 \\
23\end{array}$ & $\begin{array}{r}15(24 \cdot 6) \\
5(12 \cdot 2) \\
5(33 \cdot 3) \\
7(30 \cdot 4)\end{array}$ & $\begin{array}{l}45 \\
29 \\
17 \\
19\end{array}$ & $\begin{array}{r}6(13 \cdot 3) \\
13(44 \cdot 8) \\
3(17 \cdot 6) \\
7(36 \cdot 8)\end{array}$ & $\begin{array}{r}106 \\
70 \\
32 \\
42\end{array}$ & $\begin{array}{r}21(19 \cdot 8) \\
18(25 \cdot 7) \\
8(25 \cdot 0) \\
14(33.3)\end{array}$ \\
\hline Total & 140 & $32(22 \cdot 9)$ & 110 & $29(26 \cdot 4)$ & 250 & $61(24 \cdot 4)$ \\
\hline
\end{tabular}

disease in children in India after ingestion of aflatoxin-contaminated foods, ${ }^{20} 21$ and epidemiological and clinical correlations between Reye's syndrome in children and dietary exposure to aflatoxin in Thailand. ${ }^{22}{ }^{23}$

These reports confirm veterinary observations of the vulnerability of the liver to injury by aflatoxins and the greater susceptibility of the young and malnourished to these toxins. Apart from the evidence concerning hepatoma, clinical evidence of aflatoxin poisoning in man is based mainly on acute pathology precipitated by short exposure to high levels of aflatoxins. The effect of longterm exposure to aflatoxins in childhood has received little study. In the light of our findings there is clearly a need for such investigation, especially in areas where protein energy malnutrition is endemic.

The more frequent detection and higher mean concentrations of aflatoxins in the sera of children with kwashiorkor than in normal controls might reflect greater exposure to aflatoxins in the kwashiorkor group, or they may be the result of impaired ability to transport and excrete these substances consequent on the metabolic derangements associated with kwashiorkor. To clarify the cause we are now performing further studies to investigate whether the dietary intake of aflatoxin in children with kwashiorkor is higher than in other groups by measuring aflatoxin values in food cooked in the homes (food on the plate) of all groups of patients. We are also analysing aflatoxin concentrations in the serum and urine of individuals to determine the relation between urinary excretion and serum concentrations of aflatoxin. Whatever the explanation may prove to be, children with kwashiorkor are clearly at greater risk from aflatoxin than normal children. A condition could be envisaged in which, after an initial insult to the liver, impaired ability to handle and excrete aflatoxins creates a vicious cycle in which serum aflatoxin values rise as the ability to handle these substances progressively declines.

The detection of aflatoxicol, a metabolite of aflatoxins $B_{1}$ and $\mathrm{B}_{2}$, in children with kwashiorkor or marasmic kwashiorkor but not in controls or marasmic children indicates some fundamental difference in the metabolism of aflatoxins in the two categories of patients. Whether this is causally related to kwashiorkor or is a consequence of the disease provides an intriguing problem for further study.

This investigation is being supported by Oxfam, the International Development Research Centre, Canada, and the Overseas Development Administration of HM Government. 


\section{References}

1 Alleyne GAO, Hay RW, Picon DI, Stanfield JP, Whitehead RG. Proteinenergy malnutrition. Edward Arnold: London, 1976.

2 Coward WA, Lunn PG. The biochemistry and physiology of kwashiorkor and marasmus. Br Med Bull 1981 ;44:19-24.

3 Williams CD. A nutritional disease of children associated with a maize diet. Arch Dis Child 1933;8:423.

4 Williams CD. Kwashiorkor a nutritional disease of children associated with maize diet. Lancet 1935 ;ii:1151.

5 Trowell HC, Davies JN, Dean RFA. Kwashiorkor. London: Edward Arnold, 1954.

${ }^{6}$ Gopalan C. Kwashiorkor and marasmus: evolution and distinguishing features. In: McCance RA, Widdowson RM, eds. Calorie deficiencies and protein deficiencies. Edinburgh and London: Churchill Livingstone, 1968:49-58.

7 Tung HT, Wyatt RD, Thaxton P, Hamilton PB. Concentrations of serum proteins during aflatoxicosis. Toxicol Applied Pharmacol 1975;34:320-6.

${ }^{8}$ Hamilton PB. Inter-relationships of mycotoxins with nutrition. Federation Proceedings 1977;36:1899-1902.

${ }^{9}$ Richard JL. In: Rosenberg P, ed. Toxins: animal, plant and microbial Oxford: Pergamon, 1978:810.

10 Nwokolo C, Okonkwo P. Aflatoxin load of common food in savanna and forest regions of Nigeria. Trans $R$ Soc Trop Med Hyg 1978;72:329-32.

11 Goldblatt LA. Aflatoxin. New York: Academic Press Inc, 1969.

12 Waldman E. Seasonal variation in malnutrition in Africa. Trans $R$ Soc Med Hyg 1973;67:431.

13 Poskitt EM. Seasonal variation in infection and malnutrition at a rural paediatric clinic in Uganda. Trans $R$ Soc Trop Med Hyg 1972;66:931-6. 14 Dossetor J. The pattern of malnutrition in Zaria. $\mathcal{F}$ Trop Pediatr and Envir Child Health 1975;21:16-9.

15 Wellcome Trust Working Party, Lancet 1970:ii:302.

${ }_{16}$ Nelson DB, Kimbrough R, Landrigan DS, Hayes AW, Yang GC, Benanides J. Aflatoxin and Reye's Syndrome. A case control study. Pediatr 1980;60:865-9.

17 Horwitz W, ed. Official methods of analysis of the Association of Official Analytical Chemists. 12th ed. Washington, DC: AOFAC, 1975:7.

${ }^{18}$ Holaday CE, Lansden J. Rapid Screening method for aflatoxins in a number of products. F Agric Food Chem 1975;23:1134-6.

19 Linsell CA, Peers FC. Aflatoxin and liver cell cancer. Trans $R$ Soc Trop Med Hyg 1977;71:471-3.

${ }^{20}$ Amla I, Kamala CS, Gopalakrishna GS, Jayaraj AP, Sreenivasamurthy V, Parpia HAB. Cirrhosis in children from peanut meal contaminated by aflatoxin. Am $\mathcal{F}$ Clin Nutr $1971 ; 24: 609-14$.

${ }^{21}$ Krishnamachari KAVR, Ramesh V, Bhat VN, Tilak TBG. Investigations into an outbreak of hepatitis in parts of Western India. Indian 7 Med Res $1975 ; 63: 1036-49$.

22 Olson LC, Bourgeois CH, Cotton RB, Harikul S, Grossman RA, Smith TJ. Encephalopathy and fatty degeneration on the viscera in North eastern Thailand. Clinical syndrome and epidemiology. Pediatrics 1971; 47:707-16.

${ }^{23}$ Shank RC, Bourgeois CH, Keschamras N, Chandavimol P. Aflatoxins in autopsy specimens from Thai children with an acute disease of unknown aetiology. Food Cosmet Toxicol 1971;9:501-7.

(Accepted 16 August 1982)

\title{
Antenatal screening by measurement of symphysis-fundus height
}

\author{
JOHN P CALVERT, ERNEST E CREAN， ROBERT G NEWCOMBE，JAMES F PEARSON
}

\begin{abstract}
A study was undertaken to assess the value of symphysis-fundus measurement as a screening procedure for intrauterine growth retardation. The reproducibility of this measurement was investigated in two groups of six patients, each measured six times by six different observers. The intraobserver coefficient of variation was $4.6 \%$ and the interobserver coefficient of variation $6 \cdot 4 \%$. There was no evidence that experience aided consistency. A chart of symphysis-fundus measurements derived from Cardiff data was found to be similar to others previously published, and one measurement below the 10 th centile identified $64 \%$ of pregnancies in which the eventual birth weight was below the 10th centile for gestational age.

Symphysis-fundus measurement is a useful screening test; one chart could be used for any Caucasian population and should be incorporated into the maternity services "co-operation card."
\end{abstract}

\section{Introduction}

In 1953 Rumbolz and McGoogan ${ }^{1}$ showed the association between reduced growth of the uterine fundus and intrauterine

\footnotetext{
Departments of Obstetrics and Gynaecology and Medical Statistics, Welsh National School of Medicine, Heath Park, Cardiff CF4 4XN JOHN P CALVERT, MA, MRCOG, lecturer in obstetrics and gynaecology ERNEST E CREAN, MRCOG, registrar in general practice ROBERT G NEWCOMBE, PHD, FSS, lecturer in medical statistics JAMES F PEARSON, MD, FRCOG, reader in obstetrics and gynaecology
}

growth retardation. Beazley and Underhill in $1970^{2}$ showed wide patient variation in the height of the uterine fundus above the symphysis pubis (the symphysis-fundus height) and questioned the value of such measurements. The technique, although simple and inexpensive, has never been widely accepted, and uterine size continues to be recorded in various ways such as centimetres or "finger breadths" from the umbilicus or xiphisternum, or, simply, equivalent to $\mathrm{x}$ weeks.

In the last decade the difficulty of diagnosing intrauterine growth retardation on abdominal palpation has been recognised. Even experienced obstetricians detect fewer than $50 \%$ of cases, ${ }^{3-5}$ and the diagnostic value of current hospital antenatal care has been questioned. ${ }^{6}$ In an attempt to facilitate the diagnosis of intrauterine growth retardation several charts of the symphysis-fundus measurement have been made. ${ }^{7-10}$ Despite this the technique is still not popular, probably because of the lack of agreed principles (table I), the suggested need for an individual curve for each maternity unit, ${ }^{10}$ and the anticipated problem of observer variation.

To assess the magnitude of these problems we undertook the two-part study reported here. In the first part we assessed the reproducibility of symphysis-fundus measurements made by the same observer and by different observers, and in the second part

TABLE I-Different principles used in three charts of symphysis-fundus measurements

\begin{tabular}{|c|c|c|}
\hline Reference & Derivation of chart & Abnormal result \\
\hline Westin $^{8}$ & Mean birth weight \pm 1 SD & $\begin{array}{l}\text { One value }>2 \mathrm{~cm} \text { below mean or } \\
\text { three consecutive static or } \\
\text { declining values }\end{array}$ \\
\hline Belizan et $a l^{\circ}$ & $\begin{array}{l}\text { Birth weight between } \\
\text { 10th and } 90 \text { th centiles }\end{array}$ & One value $<10$ th centile \\
\hline Quaranta $e t a l^{10}$ & $\begin{array}{l}\text { Birth weight between } \\
25 \text { th and } 90 \text { th centiles }\end{array}$ & $\begin{array}{l}\text { Two consecutive or three isolated } \\
\text { values }<10 \text { th centile }\end{array}$ \\
\hline
\end{tabular}

